\title{
Nemfémes szervetlen funkcionális anyagok és nanoszerkezetek fejlesztése a Pannon Egyetemen
}

\author{
ENISZNÉ BÓDOGH Margit, ${ }^{a}$ HEGEDÜS-DOBRÁDI Annamária, ${ }^{\mathrm{b}} \mathrm{JAKAB}$ Miklós, ${ }^{\mathrm{a}}$ \\ KORIM Tamás, ${ }^{a}$ SOÓSNÉ BALCZÁR Ida, ${ }^{a}$ BOROS Adrienn, ${ }^{a}$ KOVÁCS András, ${ }^{a}$ és \\ KRISTÓFNÉ MAKÓ Évaa,* \\ aPannon Egyetem, Anyagmérnöki Intézeti Tanszék, Egyetem utca 10., 8200 Veszprém, Magyarország \\ ${ }^{b}$ Nemzeti Szakértői és Kutató Központ, Mosonyi utca 9., 1087 Budapest, Magyarország
}

\section{Bevezetés}

A Pannon Egyetem (névváltozás előtt Veszprémi Egyetem) Anyagmérnöki Intézeti Tanszékén (névváltozás elött Szilikát- és Anyagmérnöki Tanszékén) az egyetem alapítása óta (kb. 70 éve) folyik szakmailag elismert kutatómunka a nemfémes szervetlen funkcionális anyagok és nanoszerkezetek területén.

Ezen belül az egyik fontos kutatási terület a bioaktív kerámiákhoz kapcsolódik. A kalcium-foszfát alapú bioaktív anyagok alkalmasak az élő csonttal való közvetlen kapcsolat kialakítására, így kiválóan alkalmazhatók csontpótlásra. ${ }^{1-3}$ Klinikai alkalmazásukat mechanikai szilárdságuk korlátozza, így a kedvezőbb szilárdsági tulajdonságokkal rendelkező apatit, whitlockit és wollastonit kristályos fázisokat tartalmazó üvegkerámiákat egyre gyakrabban alkalmazzák..$^{4-8}$ Kutatásaink során olyan bioüvegkerámiákat állítottunk elő, ahol az üveg mátrixban különböző adalékanyagok segítségével alakítottuk ki a kristályos fázist.6,7,9 A mágneses vasoxidot tartalmazó hidroxiapatit biokerámiák (nanokompozitok) egyre nagyobb szerepet játszanak a gyógyászatban, különböző terápiás alkalmazásokban. ${ }^{10-14}$ Kutatásaink során különböző nedves kémiai módszerekkel állítottunk elő nanokompozitokat, amelyeknek vizsgáltuk fizikai, kémiai és biológiai tulajdonságait. ${ }^{13,14}$

Másik jelentős kutatási területünk az alkáli aktivált kötőanyagok fejlesztése. Az alkáli aktivált kötőanyagok (AAC-k) közismertebb, bár nem teljesen pontos elnevezés szerint a geopolimerek, napjaink ígéretes szerkezeti anyagai közé tartoznak. Fejlesztésük fö mozgatórugója azon elképzelés volt, ami szerint reális alternatívát jelenthetnek a klasszikus kötőanyagok, főként a hagyományos portlandcement (OPC) helyettesítésére. ${ }^{15-19}$ Mára kissé árnyaltabbá vált a kép, sok számítást, modellkísérletet végeztek, ami alapján a klasszikus építőipari felhasználhatóság már kevésbé mutat egyértelmü képet. Az viszont bizonyos, hogy az AAC-k számos kedvező sajátsággal bírnak, azok kiaknázása nagyobb hozzáadott értékü termékek előállításának lehetőségét rejti magában. A tanszékünkön folyó kutatások ezen speciális területek feltárását célozzák. ${ }^{20,21}$
Harmadik meghatározó kutatási területünk a kaolinit nanoszerkezetekhez kötődik. Korunk jelentős müszaki fejlődése indokolja újabb és újabb, egyre fejlettebb nanoszerkezetek kialakítását. ${ }^{22,23}$ A szigorodó környezetvédelmi és müszaki elvárások miatt a nanokompozit anyagrendszerekben alkalmazható mátrix és a diszperz fázis fejlesztése súlyponti feladat. A kaolinit nanoszerkezetek (pl. nanotekercsek) többek között polimer nanokompozitokban jól alkalmazhatók diszperz fázisként. ${ }^{22,23}$ Ezek a nanotekercsek nem vezetik az elektromos áramot, tüzgátló hatásúak és fehér színüek. Poláris felületük megfelelően módosítható, hogy az a mátrixban jobban kötődjön. Tanszékünkön az elmúlt években fontos eredményeket értünk el a kaolinit nanoszerkezetek fejlesztése terén, ahol kémiai, szerkezeti és morfológiai vizsgálatokkal újszerü és hatékonyabb elöállítási eljárást fejlesztettünk ki. ${ }^{24-31}$

\section{Bioaktív kerámiák fejlesztése}

A Ca-foszfát bázisú bioanyagok alkalmasak az élő csonttal való közvetlen kötés kialakítására, ami lehetővé teszi csontpótlásra való felhasználásukat. Kis mechanikai szilárdságuk azonban korlátozza klinikai alkalmazásukat. Ez a hátrányos tulajdonság apatit $\left(\mathrm{Ca}_{10}\left(\mathrm{PO}_{4}\right)_{6}(\mathrm{OH}, \mathrm{F})_{2}\right)$, whitlockit $\left(\mathrm{Ca}_{3}\left(\mathrm{PO}_{4}\right)_{2}\right.$ és wollastonit $\left(\mathrm{CaSiO}_{3}\right)$ kristályos fázisokat tartalmazó üvegkerámiák alkalmazásával nagyban kiküszöbölhető. Az üvegkerámiák bioaktivitását elsődlegesen az üveg mátrix kémiai összetétele, a benne található kristályos fázisok mennyisége, részecske mérete és eloszlása határozza meg. A wollastonit kristályos fázis egyrészt elősegíti az apatit irányított kristályosítását, másrészt szálas szerkezete révén kedvezően befolyásolja az üvegkerámia mechanikai tulajdonságait, így e termékek nagyobb igénybevételnek kitett csontok pótlására is alkalmasak. Ezen felületaktív anyagokból a testnedvek hatására bekövetkező fokozatos kalcium kilépés mellett a felületen $\mathrm{SiO}_{2}$ gél réteg keletkezik, melyben a kalcium a testnedvekben levő foszforral amorf kalcium-foszfátot képez, ami ezután kristályos karbonát-hidroxiapatittá alakul. Mindez lehetővé teszi a bioanyag és az élő csontszövetek közötti, karbonát-hidroxiapatit rétegen keresztül megvalósuló, kö-

Tel.: +3688624000 / 6065; e-mail: makoe@almos.uni-pannon.hu. 
tőszövet nélküli közvetlen gyors kötés kialakulását. A szövetképződés, az implantátum stabil beépülése szempontjából kedvező a nem túl gyors oldódás, amit elsődlegesen a $\mathrm{Ca}: \mathrm{P}$ atomarány $(>1,5)$ határoz meg. ${ }^{1,2}$ Így a biológiai apatit képlete: $(\mathrm{Ca}, \mathrm{Mg}, \mathrm{Na})_{10}\left(\mathrm{PO}_{4}, \mathrm{HPO}_{4}, \mathrm{CO}_{3}\right)_{6}(\mathrm{OH}, \mathrm{F})_{2}$. A kollagén a csontok rugalmasságát és szívósságát, míg a hidroxiapatit a keménységét adja. Az emberi szervezetben két különböző típusú - szivacsos és tömör - csont található, s a csontváz minden csontján egy nagyobb sürüségü külső réteg van jelen. $^{3}$

Kísérleti munkánk során olyan bioüvegkerámiákat állítottunk elö, ahol az üveges mátrixban található Ca-P tartalmú kristályos fázisok kialakítása egyrészt analitikai tisztaságú vegyszerekből lecsapásos módszerrel előállított hidroxiapatittal, ${ }^{4,5}$ másrészt különböző módon kezelt, az emberi csontokhoz hasonló nyomelemeket tartalmazó állati (szarvasmarha) csont örleménnyel történt. ${ }^{6,7} \mathrm{~A}$ nagy tisztaságú alapanyagok $\left(\mathrm{SiO}_{2}, \mathrm{CaCO}_{3}, \mathrm{P}_{2} \mathrm{O}_{5}, \mathrm{Na}_{2} \mathrm{CO}_{3}, \mathrm{MgO}, \mathrm{K}_{2} \mathrm{CO}_{3}\right)$ keverékének $1300^{\circ} \mathrm{C}$-os olvasztásával és gyors hütésével előállított, $1100^{\circ} \mathrm{C}$-on olvadó bázisüveg fritt őrlemény a röntgendiffrakciós fázisösszetétel vizsgálat szerint a 82 $\mathrm{m} / \mathrm{m} \%$ üveges/amorf fázis mellett $\beta$-whitlockit, wollastonit, valamint különböző szerkezetű $\mathrm{SiO}_{2}$ kristályos fázisokat tartalmazott. Ezen $<100 \mu \mathrm{m}$ szemcseméretü bázisüvegporból kiindulva, 20 és $25 \mathrm{~m} / \mathrm{m} \%$ csapadékos módszerrel elöállított, $950^{\circ} \mathrm{C}$-on 1 órán át hökezelt hidroxiapatit, illetve különbözö módon kezelt (fehérje mentesített $965^{\circ} \mathrm{C} / 10 \mathrm{~h}$ (SBB) és $965^{\circ} \mathrm{C} / 10 \mathrm{~h}+1430^{\circ} \mathrm{C} / 10 \mathrm{~h}$ (HTSBB)) állati csontőrlemények hozzáadásával, hidraulikus préseléssel pasztillákat készítettünk. Az apatit adalék a röntgendiffraktométerrel végzett fázisösszetétel vizsgálat szerint a $87 \mathrm{~m} / \mathrm{m} \%$ hidroxiapatit mellett $13 \mathrm{~m} / \mathrm{m} \% \beta$-whitlockitot tartalmazott, $\mathrm{s}$ a lézeres szemcseméret analízis szerint 16\% $5 \mu \mathrm{m}$-nél kisebb szemcsék mellett a döntő hányadot az 5-300 $\mu \mathrm{m}$ tartományba eső szemcsék alkották. A természetes eredetű, állati csontból nyert SBB és HTSBB adalékok a Ca és a $\mathrm{P}$ mellett (hullámhossz-diszperzív röntgenfluorescens spektrométerrel meghatározva) számos kis mennyiségű kísérő elemet tartalmaztak. A röntgendiffrakciós fázisösszetétel vizsgálat szerint a $965^{\circ} \mathrm{C}$-on hökezelt (SBB) csontőrlemény a hidroxiapatit mellett nagyobb hányadban tartalmaz $\beta$-whitlockitot, míg az $1430^{\circ} \mathrm{C}$-on égetett, majd gyorsan hütött HTSBB őrleményben a hidroxiapatit és a $\beta$-whitlockit mellett megjennek az $\alpha$-whitlockit, valamint a nagy hömérsékleten stabil $\mathrm{Ca}_{4} \mathrm{P}_{2} \mathrm{O}_{9}$ és $\alpha-\mathrm{CaP}_{2} \mathrm{O}_{6}$ fázisok is, melyek nagymértékben befolyásolhatják a bioaktivítás szempontjából fontos oldódási sebességet.

Az adalék anyagok bázisüveg-fritt őrleményhez való különböző mennyiségű hozzáadásával, és az előállítási paraméterek szisztematikusan változtatásával állítottuk elö a különböző mennyiségű és szemcseméretű Ca-foszfát és wollastonit kristályos fázisokat tartalmazó, eltérő biológiai és mechanikai tulajdonságokkal rendelkező bioaktív üvegkerámiákat. A röntgendiffrakciós felvételek szerint az SBB adalékkal készített üvegkerámiákban minden égetési hőmérsékleten a $\beta$-whitlockit csúcsok nagyobb intenzitás- sal jelentek meg, mint a mesterséges hidroxiapatit esetén. A pasztillák 1000,1050 és $1100^{\circ} \mathrm{C}$ hőmérsékleten történő égetésével 0-26 V/V\% látszólagos (nyílt) porozitással rendelkező üvegkerámiákat kaptunk, ahol a porozitást az adalékok fázisösszetétele kevésbé, azok szemcsemérete és mennyisége erősebben, az égetési hőmérséklet pedig a legintenzívebben befolyásolta. $1100^{\circ} \mathrm{C}$-on nagyon tömör, közel zérus porozitású termékek állíthatók elö. Mindez jelentősen befolyásolja a mechanikai tulajdonságokat, oldhatóságot, az élö szervezetbe való beépülést, s egyben lehetővé teszi az adott tulajdonságok szabályozását is. A bioaktív implantátumoknál az implantátum élö szervezetbe való hatékony gyors beépüléséhez >100 $\mu \mathrm{m}$ átmérőjü pórusok szükségesek, melyekbe lehetséges a vérerek benövése. Az égetési hőmérséklet növelésével, a legnagyobb szemcséket illetve szemcseaggregátumokat tartalmazó mesterséges hidroxiapatit adalékkal készített minták kivételével, nő a Vickers-féle mikrokeménység és ezáltal a kopásállóság. A legnagyobb keménység a $965^{\circ} \mathrm{C}$-on hőkezelt SBB adalékot tartalmazó minták 1000 és $1100^{\circ} \mathrm{C}$-os égetésénél adódott.

Az üvegkerámiák bioaktivitását szimulált testfolyadékban $36,5^{\circ} \mathrm{C}$-on végzett 6 órás, 1, 3, 7 és 21 napos állásidő után vizsgáltuk. A testfolyadék Ca és $\mathrm{P}$ tartalmának röntgenfluoreszcens spektrométeres vizsgálata alapján a mesterséges, durvább szemcseméretü hidroxiapatit oldhatósága kisebb, ${ }^{8}$ mint az adott állati csont adalékoké és az oldásidő függvényében kevésbé változik. Ekkor az égetési hőmérséklet növelésével, ezáltal a porozitás csökkenésével, a kioldott Ca mennyisége csökken. A $965^{\circ} \mathrm{C}$-on égetett (SBB), ezáltal $\beta$-whitockitot tartalmazó állati csont adalékkal készített mintáknál az üvegkerámiákra jellemző szokásos oldódási sebesség adódott, míg az $\alpha$-whitockit tartalmú HTSBB üvegkerámiák gyorsabb oldódást mutattak. A mesterséges hidroxiapatitot tartalmazó, valamint a fö tömegében $\beta$-whitlockit tartalmú SBB mintáknál a szimulált testfolyadékos kezelés hatására nagyobb átlagos szemcseméretü, inhomogén szemcseméret eloszlású apatit képződött a felületen, míg a nagyobb oldódási sebességű $\alpha$-whitlockitot tartalmazó HTSBB adaléknál a felületen kisebb méretü, közel homodiszperz apatit részecskék keletkeztek. Mindez arra utal, hogy a testfolyadékos oldás hatására a felületen újonnan kiváló apatit kristályosodási sebessége hidroxiapatitból és $\beta$-whitlockitból gyorsabb, mint $\alpha$-whitlockitból. A különböző adalékokat tartalmazó üvegkerámiák szimulált testfolyadékos oldásakor keletkező apatit rétegek az eredetieknél kisebb keménységűek. A legnagyobb keménység csökkenés az $\alpha$-whitlockitot tartalmazó, a legkisebb kristályosodási sebességü, legfinomabb szemcseméretü rétegnél adódott. Az üvegkerámiák mechanikai szilárdságát vizsgálva a legnagyobb hajlító szilárdság értékeket a 30 $\mathrm{m} / \mathrm{m} \%$ SBB adalékot tartalmazó (88 MPa), valamint a 20 $\mathrm{m} / \mathrm{m} \%$ HTSBB adalékkal készített ( $88 \mathrm{MPa}) 1100^{\circ} \mathrm{C}$-on hőkelt mintáknál kaptuk, mely értékek több mint kétszeresei a bázisüveg frittből készített próbatestnél mért értéknek (41 $\mathrm{MPa})$. A kisebb hömérsékleten hőkezelt minták nyomószilárdsága (57-155 MPa) a tömör csontokéhoz (100-230 MPa), míg a nagyobb $\left(1100^{\circ} \mathrm{C}\right)$ hőmérsékleten égetetteké (71-423 
$\mathrm{MPa})$ inkább a tömör hidroxiapatitéhoz (300-900 MPa) és a tömör $\left(\mathrm{Ca}_{3}\left(\mathrm{PO}_{4}\right)_{2}\right.$-éhoz (450-650 $\left.\mathrm{MPa}\right)$ hasonló. Ezen értékeket a kereskedelmi forgalomban kapható BIOVERIT II. bioüvegkerámia nyomószilárdságával (450 MPa) és hajlítószilárdságával (90-140 MPa) összehasonlítva, az általunk elöállított $25 \mathrm{~m} / \mathrm{m} \% \mathrm{SBB}$ adalékot tartalmazó $1100^{\circ} \mathrm{C}$-on égetett mintánál $83 \mathrm{MPa}$ hajlító- és $424 \mathrm{MPa}$ nomószilárdság adódott. Megállapítható továbbá, hogy a különböző módon hőkezelt állati csontőrlemény adalékkal készített üvegkerámiák kétszer nagyobb hajlítószilárdsággal rendelkeztek, mint a csapadékos módszerrel elöállított hidroxiapatitot tartalmazók ( 47 MPa). Az implantátumok gyakorlati felhasználásánál nagyobb jelentőségü hajlítószilárdságot az égetési hőmérséklet növelése előnyösen befolyásolta, ugyanis az égetési hőmérséklet $1100^{\circ} \mathrm{C}$-ra növelése az állati csontőrlemény adalékot tartalmazó mintáknál a hajlító szilárdság közel kétszeres növekedését eredményezte az adalék nélküli mintákhoz képest. A $25 \mathrm{~m} / \mathrm{m} \%$ SBB adalékkal készített, $1000^{\circ} \mathrm{C}$-on égetett, porított üvegkerámia saválló acéllemezre, titán ötvözetre (Ti6A14V) és korund lapra történő plazmaszórásával jól tapadó, megfelelő porozitású (2-6 V/V\%) és szilárdságú 115-266 $\mu \mathrm{m}$ vastag bevonatokat állítottunk elö, melyek bioaktivitása közel azonos a tömbi anyagokéval. ${ }^{9}$

Eredményeink alapján a különböző módon előkezelt, az emberi csontokhoz hasonló nyomelemeket tartalmazó állati csont őrlemények előnyösen alkalmazhatók bioüvegkerámiák gyártására. A bázisüveg-fritt őrleményhez való adalékolásukkal jobban szabályozható minőségű, az adott felhasználási célnak jobban megfelelő tulajdonságú, az élő szervezetbe kedvezőbben beépülö üvegkerámia implantátumok állíthatók elő. Fehérje mentesített, hőkezelt állati csont adalékot tartalmazó üvegkerámiák $1100^{\circ} \mathrm{C}$-os égetésével a mesterséges hidroxiapatitot tartalmazókénál nagyobb, a tömör csontokéhoz hasonló hajlítószilárdságú bioüvegkerámiák állíthatók elő. Ezen állati csont adalékkal készített bioüvegkerámiák saválló acél és titánötvözet felületen plazmaszórással jól kötődő, a tömbi anyagokéval azonos bioaktivitású bevonatokat adtak.

A mágneses vasoxidot tartalmazó hidroxiapatit biokerámiák (nanokompozitok) egyre nagyobb szerepet játszanak a gyógyászatban, így előnyösen felhasználhatók MRI vizsgálatoknál kontrasztanyagként, gyógyszerek adott testrészbe történő szállításához, a rákos elváltozások hipertermiás kezeléséhez. ${ }^{10-13}$ Ezen nanokompozitok előállításánál elsősorban a biokompatibilis és bioaktív hidroxiapatitot használják a nagy mágneses momentummal rendelkező magnetit részecskék beágyazására, mivel megakadályozza a magnetit részecskék paramágneses tulajdonságának romlását eredményező szemcsenövekedését és aggregációját. A mágneses nanokompozitok előállítását kezdetben kétféle - egylépcsős és kétlépcsős - eljárással végeztük, ${ }^{14}$ annak tisztázására, hogy melyik eredményez jobb minőségű terméket. Az egylépcsős eljárás során Ansar és munkatársai által alkalmazott módon $\mathrm{Ca}\left(\mathrm{NO}_{3}\right)_{2} \cdot 4 \mathrm{H}_{2} \mathrm{O}$ és $\left(\mathrm{NH}_{4}\right)_{2} \mathrm{HPO}_{4}$ oldatokból, ${ }^{12}$ valamint $\mathrm{FeCl}_{2} \cdot 4 \mathrm{H}_{2} \mathrm{O}$ és $\mathrm{FeCl}_{3}$ sósavban fel- oldott 1:2 mólarányú keverékéből egyidejüleg történt a hidroxiapatit és a magnetit lecsapatása. A kétlépcsős eljárás esetén csapadékos módszerrel előzetesen elöállított, ${ }^{5}$ mosott hidroxiapatit gélhez adtuk az előzővel azonos paraméterek ( $\mathrm{pH}$-érték 12 és $70^{\circ} \mathrm{C}$ ) alkalmazásával a sósavban feloldott $\mathrm{FeCl}_{2} \cdot 4 \mathrm{H}_{2} \mathrm{O}$ és $\mathrm{FeCl}_{3}$ keveréket, vagyis az előzetesen elöállított hidroxiapatit gélbe ágyaztuk a vaskloridok oldatából lecsapatott magnetit részecskéket. A kétféle módszerrel kapott 5-40 m/m\% magnetit tartalmú kompozitok fázisösszetételének, szemcseszerkezetének, morfológiájának, szimulált testfolyadékban való oldhatóságának, mágneses tulajdonságának és színinger jellemzőinek vizsgálata alapján bebizonyosodott, hogy mindkét módszerrel lehetséges paramágneses nanokompozitok előállítása, melyek tulajdonságai azonban eltérnek.

A keletkező fázisok kristályosodottsági foka és mérete alapján a kétféle módszerrel eltérő bioaktivitású és szuperparamágneses tulajdonságú kompozitok állíthatók elő. A rácsparaméterek vizsgálata alapján csupán az egylépcsős módszernél figyelhető meg a $\mathrm{Fe}^{3+}$ ionok hidroxiapatit kristályszerkezetébe, a hexagonális csatornákba való beépülése, ami csökkenti a szimulált testfolyadékban való oldhatóságot, s ezáltal felhasználható az oldhatóság szabályozására. A mágneses nanokompozitok színingerjellemzőinek vizsgálata alapján a világossági tényező (L) értéke a mágneses szuszceptibilitással összhangban változik, így a kevésbé időigényes színmérés eredményeiből is következtetni lehet a mágneses tulajdonságok változására.

A vizsgálati eredmények alapján a kétféle módszerrel eltérő mágneses tulajdonságú és oldhatóságú mágneses nanokompozitok állíthatók elő, azonban az egylépcsős eljárással készítettek egyrészt kedvezőbb szuperparamágneses tulajdonságokkal rendelkeztek, másrészt kisebb oldhatóságukból adódó nagyobb stabilitásuk alapján is alkalmasabbak a gyakorlati felhasználásra.

\section{Alkáli aktivált kötőanyagok fejlesztése}

A különböző cementek gyártási kapacitása a 2010-es években elérte az évi 4 milliárd tonnát, a belölük készült betonok pedig a víz után az emberiség legnagyobb menynyiségben használt anyagává váltak. Ez egyben azt is jelenti, hogy napjainkban alig készül olyan mütárgy, ahol ne használnának cementet, illetve az abból készült betont. Minden kedvező tulajdonságuk mellett egyre nagyobb gondokat okoz azonban a környezetre gyakorolt káros hatásuk. Kis túlzással elmondható, hogy 1 tonna cement előállítása 1 tonna $\mathrm{CO}_{2}$ emissziójával jár, ${ }^{18,19}$ aminek jelentős része nem is csökkenthető, hiszen az egyik fö nyersanyagból, a mészkőből - a kémia törvényeinek engedelmeskedve - az égetés során mindig felszabadul a $\mathrm{CO}_{2}$. A másik fó probléma a tájrombolás, a hatalmas mészkő-igény miatt a szó legszorosabb értelmében mészkő hegyek tünnek el a bányászat során. Ezekre a problémákra már hosszú ideje keresik a megoldást a szakemberek, és sokáig úgy vélték, az alkáli aktivált szervetlen polimerek megoldást jelenthetnek. A 
kutatások előrehaladtával a hagyományosnak tekinthetö, kötőanyagként szolgáló felhasználás mellé felzárkózott az egyedi, unikális sajátságokkal bíró termékek - kompozitok, katalizátor hordozók, hőszigetelő sajátságú anyagok - fejlesztése is.

Tény, hogy alkáli aktivált cementek elöállítására csak olyan kiindulási komponensek alkalmasak, amelyek már eleve reaktív állapotúak. A kellő reaktivitás elérésére szinte kizárólag hőkezelés szolgált, mint például a granulált kohósalak, szénpernye, vagy a metakaolin esetén. Kísérleteink során bizonyítottuk, hogy a hőkezelés mellett a mechanokémiai aktiválás is alkalmas a puccolános sajátságok javítására. ${ }^{20}$ Ennek során megállapítottuk, hogy bolygómalomban történő őrléssel előkészített alapanyagok nagyobb reaktivitással bírnak és a belölük készült termékek jobb mechanikai szilárdsággal rendelkeznek, mint a termikusan kezeltek (a metakaolin esetén például a nyomószilárdság kb. $44 \mathrm{MPa}$ ) amellett, hogy a fajlagos energia-bevitel kisebb. Kísérleteink során egy jelzőszámot, az ún. amorfizációs fokot definiáltunk, aminek segítségével előre jósolható az alapanyag reakciókészsége és így a kötőanyag szilárdsága is. Az amorfizáció és a kötésviszonyok alakulása - mind a termikus, mind a mechanokémiai aktiválás esetén - jól nyomon követhető röntgendiffrakciós és Fourier-transzformációs infravörös (FT-IR) technika alkalmazásával. Ez utóbbi módszer esetén a két eljárás során kialakuló amorf anyagrendszer összetételének atomi szinteken jelentkező különbségei is detektálhatók. Ezen megfontolások alapján sikeresen aktiváltunk olyan hulladékanyagot, mint a kristályos kohókő, ${ }^{21}$ ami összetételében igen hasonlít a granulált kohósalakhoz, azonban kiindulási állapotában tökéletesen kristályos, így teljesen inert. A kidolgozott paraméterek mentén végzett mechanokémiai aktiválás hatására reaktív alapanyag nyerhető, ami nagyobb szilárdságú terméket eredményez, mint a granulált kohósalakból készítettek és a szilárdság abszolút értéke is számottevő (49 MPa).

Az AAC-kel kapcsolatos kutatásaink egyik hangsúlyos irányvonalát az ipari hulladékanyagok felhasználhatóságának vizsgálata jelenti. Az már közismert tény, hogy a salak, pernye alkalmas erre a célra, de léteznek olyan komponensek is, amelyekre eddig kevesebb figyelmet fordítottak. Ilyen az építési hulladékanyagok közül a beton. Mivel a betoniparban súlyos problémákat okoz az adalékanyag egyre növekvő hiánya, a törmelék beton őrlésével és frakcionálásával potenciális nyersanyag nyerhető. A képződő finom frakció azonban nem alkalmas a fenti célokra, tehát nem lehet maradéktalanul eltüntetni a beton hulladékot. Ez a komponens azonban alkalmas lehet alkáli aktivált cementek előállítására, már csak azért is, mert éppen a legfinomabb szemcseméret-tartományban dúsulnak a klinkerásványok hidratációs termékei, amelyek összetétele jól korrelál az AAC-k előállításakor megkövetelt Si/Al és Na/ $\mathrm{Al}$ atomarányokkal. Kísérleteink során bizonyítottuk, hogy a megfelelő arányban alkalmazott betonőrlemény képes a geopolimerizációs folyamatok lejátszatására, megfelelő nyomószilárdságú (10 MPa) termék nyerhető. Amennyiben nagyobb szilárdság elérése szükséges, úgy valamely aktívabb alapanyag (salak, pernye, metakaolin), hozzáadásával ez gond nélkül megvalósítható.

$\mathrm{Az}$ AAC-k természetes nyersanyagokból is létrehozhatók; Magyarország például bővelkedik egy speciális, nagy amorf tartalommal bíró kőzetben, a perlitben, amelynek összetétele megfelel az új típusú kötőanyagok előállításához. Kísérleteink során egy speciális, perlit bázisú AAC duzzasztott perlit kompozit előállítása volt a célunk, amely jó hőszigetelő sajátságú építőipari termékként szolgálhat. A természetes perlit kőzetet nagyenergiájú őrléssel mechanokémiailag aktiváltuk, így megfelelő kiindulási anyagot kaptunk az alkáli aktivált cementek előállítására, a kapott nyomószilárdsági érték $37 \mathrm{MPa}$. A hőszigetelési sajátságok javítására duzzasztott perlitet használtunk, 10 m/m\% menynyiségben. Meglepő módon a szilárdsági sajátságok csak kis értékben romlottak, a hővezetési tényezô értéke pedig 0,10 és $0,15 \mathrm{~W} / \mathrm{mK}$ között változik, így elmondható, hogy a perlit bázisú AAC-k hőszigetelő sajátságú építőelemek előállítására remekül megfelelnek.

Szintén a kompozitok családjába tartozó szerkezeti anyagok fejlesztése volt a célunk, amikor AAC bázisú, gumihulladékkal adalékolt, egyben szálerősített termékek fejlesztését végeztük. Arra törekedtünk, hogy a lehető legnagyobb arányban alkalmazzunk hulladékanyagokat, így már az AAC mátrix kialakítására is salakot használtunk, a szálerősítést pedig hulladékként keletkező ún. kaowool szálak felhasználásával végeztük. Problémaként jelentkezett a gumiszemcsék hidrofób viselkedése, ami a mátrix szerkezetét, így a szilárdságot nagymértékben gyengítette. A minél intenzívebb nedvesítés elérésére a gumiszemcsék felületét és ezzel egy időben kötés-szerkezetét többféle technikával módosítottuk (lúg, szerves és szervetlen savak, UV besugárzás, hökezelés). A legjobb eredményt kénsavas kezeléssel értük el, aminek hatására csaknem 75\%-kal nőtt a szilárdság. A mikroszerkezetben bekövetkező változásokat pásztázó elektronmikroszkópos technikával követtük nyomon. Az így előállított kompozit anyagok speciális tulajdonságai közé tartozik, hogy a normál betonokhoz képest jelentősebben ellenállnak a ciklikus terheléseknek. Megállapítottuk, hogy a kötőanyagok ridegsége gumi adalékolással csökkenthető, ezáltal a ciklikusan ismétlődő mechanikai hatásokkal szembeni ellenállóképességük is javítható.

Az AAC-k további kedvező sajátsága, hogy kiválóan habosíthatók. Az AAC habok, mint környezetbarát, porózus anyagok speciális tulajdonságokkal (habzás utáni kismértékű zsugorodás, mechanikai és kémiai stabilitás, nagy hömérsékleti ellenállás) rendelkeznek, amelyek az építőipari alkalmazásokon (pl. hőszigetelés) túl lehetővé teszik különböző célú katalizátorhordozóként történő felhasználásukat is. Kutatási munkánk során elsődleges szándékunk volt metakaolin alapon, ún. kombinált eljárással (elszappanosítás/ peroxid-bontás/gélesítés) olyan megfelelöen nagy, föként nyílt porozitású ( $>50 \mathrm{~V} / \mathrm{V} \%)$ és értékelhető nyomószilárdságú ( $>1 \mathrm{MPa}$ ) habok előállítása, amelyek felületén $\mathrm{TiO}_{2}$ 
részecskék immobilizálhatók és ezáltal fotokatalitikus víztisztításnál alkalmazhatók. A minták porozitása és pórusméret-eloszlása az előállítási körülmények megfelelő megválasztásával tervezetten változtatható; közel $60 \mathrm{~V} / \mathrm{V} \%$-os nyílt porozitás is elérhető. Kísérleteink során felfedeztük, hogy az AAC habok a pórusszerkezetüktől függően önmagukban, $\mathrm{TiO}_{2}$ részecskék nélkül is képesek fotokémiai aktivitásra, akár 55\%-os bontási hatékonyság is tapasztalható. A habok adszorpciós és fotokémiai tulajdonságait (a bontó képességet) a kialakuló pórusszerkezet befolyásolja, bizonyítottuk, hogy a minták bontóképessége és morfológiája között korreláció áll fenn, ami az égetési hőmérséklettel befolyásolható, szabályozható.

Megfigyeltük, hogy a habok előállítása költség- és energiahatékonyabbá tehető a korábbi habosítási eljárások egyik klasszikus komponense, az olaj elhagyásával. Csak hidrogén peroxid alkalmazásával növelhető a minták nyílt porozitása $(75 \mathrm{~V} / \mathrm{V} \%)$ ), azonban a fotokémiai aktivitás ekkor lényegesen romlik ( $<30 \%$ bontóképesség), ami viszont $\mathrm{TiO}_{2}$ adagolással javítható ( $\left.45 \%\right)$. A geopolimer mátrixban megkötött $\mathrm{TiO}_{2}$ önmagában is pórusképző hatással bír, az alkalmazott mennyiségének azonban felső határa van $(12,5$ $\mathrm{m} / \mathrm{m} \%$ ). Bontás szempontjából az $5-15 \mathrm{~mm}^{3}$-es pórusok mennyisége a kulcsfontosságú, a nyílt és zárt pórusok méretének és mennyiségének változásai CT (computer tomography) vizsgálattal egyértelmüen nyomon követhetők.

\section{Kaolinit nanoszerkezetek fejlesztése}

A kaolinit egy kétrétegű filloszilikát, mely rendelkezik egy tetraéderes és egy oktaéderes réteggel, ahol szilícium és alumínium központi kationok vannak. ${ }^{23}$ Az egymást követö kettősrétegeket hidrogénhíd kötések tartják össze, melyek ellensúlyozzák a kettősrétegben geometriai okokból ébredő feszültségeket. Ha ezek a kötések meggyengülnek, vagy felszakadnak, a feszültségek miatt bekövetkezhet az egyedi kettősrétegek elválása és feltekeredése. ${ }^{22}$ A természetben megtalálható a kaolinit hidratált alakja a halloysit, melynek feltekeredett cső alakú kristályai vannak. A kaolinit fontos ipari nyersanyag pl. a papír-, a kerámia-, a műanyag- és a gyógyszeripar használja fel a nagy mennyiségben. Fontos tulajdonsága, hogy különbözö interkalációs eljárásokkal szerves, illetve szervetlen vendégmolekulákat lehet a rétegközi terébe juttatni. Ezek az eljárások alkalmas a különböző lelőhelyről származó kaolinitek reaktivitásának, felületi tulajdonságainak, illetve halloysit tartalmának, stb. meghatározására. Napjainkban újra a kutatások középpontjába került ez a terület, mivel a kaolinit lemezek többlépéses interkalációs módszerekkel nanotekercsekké alakíthatók, melyek így, a már széleskörüen alkalmazott szén- és halloysit nanocsövekhez hasonlóan, pl. műanyag nanokompozit anyagrendszerekben alkalmazhatók. Mivel a természetes tiszta halloysit viszonylag ritka és tulajdonságai (pl. hossz, átmérö) széles tartományban váltakoznak, ezért a tisztán nagy mennyiségben bányászható kaolinit lemezes szerkezetét nanotekerccsé átalakító eljárások fejlesztése indokolt. Ezen eljárások kutatása a nanokompozit anyagrendszerek mellett fontos a nanopórusos katalizátorok, szelektív adszorbensek, és hatóanyag nanokapszulák előállításához.

A kaolinit nanotekercsek előállítását többlépéses interkalációs és deinterkalációs kezelési lépésekkel végzik. ${ }^{22,23}$ Először kismolekulájú szerves vegyületeket (pl. dimetil-szulfoxidot) juttatunk a kaolinit kettősrétegei közé. Ekkor a kaolinit bázislaptávolsága $(0,72 \mathrm{~nm})$ megnövekszik (pl. 1,12 nm-re a dimetil-szulfoxidnál), ami röntgendiffrakcióval jól jellemezhetö, és az interkalált kaolinitfázis aránya (interkalációfok) meghatározható, mely technológiai szempontból lényeges. ${ }^{22-33} \mathrm{Az}$ első interkaláció után pl. helyettesítéssel különböző (közvetlenül be nem vihető) vegyületeket (pl. metanolt) tudunk a kaolinrétegek közé beépíteni. A kezelések során egyre nagyobb méretű vendégmolekulákat (pl. cetil-trimetil-ammónium-kloridot) tudunk a rétegközi térbe juttatni, melyeket intenzív mosással eltávolítva (deinterkaláció) a kettősrétegek a hidrogénhíd kötések hiányában feltekerednek. Ezeket a kezelési lépéseket évtizedek óta alkalmazzák kaolinit nanotekercsek előállítására, ${ }^{22,23,33}$ azonban az eljárások legtöbbször sok lépést, hosszú időt és nagy mennyiségű vegyszert igényelnek. Napjainkban tehát ezeknek az eljárásoknak a vizsgálata és hatékonyságának növelése elengedhetetlen. Tanszékünkön jelenleg a kaolinit nanoszerkezetekhez kapcsolódó kutatások célja gyors, környezetbarát interkalálószereket felhasználó, gazdaságos eljárások fejlesztése.

A kaolinit nanotekercs előállításának első prekurzor előállítási lépésénél részletesen tanulmányoztunk egy újfajta költséghatékony homogenizációs interkalációs módszert. ${ }^{24,25,27-30}$ Elemeztük a kaolinit-karbamid, kaolinit-dimetil-szulfoxid (kaolinit-DMSO), kaolinit-formamid (kaolinit-F), kaolinit-ammónium-acetát (kaolinit-AAc) és kaolinit-N-metilformamid (kaolinit-NMF) komplex előállítását befolyásoló reakció paramétereket. Az interkalációs reakció jellemzésére elsődlegesen az interkalációfokot használtuk. Az Avrami-Erofeev diffúzióra módosított egyenletet alkalmaztuk az interkaláció kinetikai leírására. ${ }^{30}$ Igazoltuk, hogy a homogenizációs módszer kiküszöböli a korábbi hagyományos oldatos és mechanokémiai módszerek gyengeségeit. Ugyanis a homogenizációs módszer nagy interkalációfokot eredményez, amihez egy nagyságrenddel kevesebb vegyszer szükséges, mint az oldatos módszernél, és a kaolinit kristályosodottságát nem rontja úgy, mint a mechanokémiai módszer. Megállapítottuk, hogy a karbamid, DMSO és NMF interkalációja erőteljesen függ az érlelési hőmérséklettől, és enyhén melegítve (60, vagy $80^{\circ} \mathrm{C}$-on) a kiindulási keverékekkel rövid idő (3 és 24 óra) alatt teljes interkalációt érhetünk el, míg szobahőmérsékleten ez tízszer annyi ideig tart. ${ }^{30} \mathrm{Az} \mathrm{F}$ interkalációját a hömérséklet kevésbé befolyásolta. Az AAc interkalációjának gyorsításához és növeléséhez a $0^{\circ} \mathrm{C}$ alatti érlelés bizonyult hatékonynak. ${ }^{24,27,28}$

A prekurzorból második lépésben nedves metanolos 1,12 nm bázislaptávolságú kaolinit-metanol komplexet alakíthatunk ki. ${ }^{22,23,33} \mathrm{Az}$ irodalomban többnyire kaolinit-DMSO 
prekurzort alkalmaznak. Kimutattuk, hogy a természetes karbamiddal képzett kaolinit komplex is alkalmas az 1,12 nm-es kaolinit-metanol komplex hatékony előállítására ( $\mathrm{kb}$. $80 \%$-ban). Szobahőmérsékleten, és $150^{\circ} \mathrm{C}$-on szárítva az interkalátum bázislaptávolsága 0,86 nm-re és 0,83 nm-re csökkent a rétegek közötti kötetlen metanol molekulák kilépésével, ahol ojtással (grafting) metoxi-csoportok épültek be a kaolinit szerkezetébe. Megállapítottuk, hogy a 0,83 nmes metoxilált kaolinit könnyen újrainterkalálható metanollal 1,12 nm-es komplexszé. A kaolinit-metanol komplex kémiai összetételét a kaolinit-DMSO és -karbamid prekurzorral is $\mathrm{Al}_{2} \mathrm{Si}_{2} \mathrm{O}_{5}(\mathrm{OH})_{3,7}\left(\mathrm{OCH}_{3}\right)_{0,3}$ képlettel jellemeztük. Kísérleti eredményeinket alátámasztották az együttmüködő molekuláris szimulációt végző kutatók eredményei.

Következő lépésként vizsgáltuk a kaolinit-cetil-trimetil-ammónium-klorid (kaolinit-CTAC) komplex szerkezetét, és előállítási lehetőségét. ${ }^{28}$ Tanulmányoztuk az első interkalálószerként használt karbamid molekulának, a metoxilált kaolinit szerkezetének és a rétegközi metanol molekulák jelenlétének a kaolinit-CTAC komplex kialakulására gyakorolt hatását. Meghatároztuk, hogy a kaolinit-CTAC komplex 3,82 nm-es bázislaptávolsággal és az $\mathrm{Al}_{2} \mathrm{Si}_{2} \mathrm{O}_{5}(\mathrm{OH})_{3,7}\left(\mathrm{OCH}_{3}\right)_{0,3}(\mathrm{CTAC})_{1,6}(\mathrm{Me})_{1,6}$ képlettel jellemezhető. Kísérleti eredményeink összhangban voltak az együttműködő molekuláris szimulációt végző kutatókéval.

Egy egyszerü és hatékony kétlépéses szolvotermális eljárást dolgoztunk ki a kaolinit-CTAC komplex (és a kaolinit nanotekercsek) közvetlen elöállítására. ${ }^{28,29} \mathrm{~A}$ kidolgozott, megközelítésében új módszer a korábbi kutatások ${ }^{25,32,33}$ tapasztalatait ötvözi úgy, hogy az eljárásban csökkenteni lehessen a reagensek mennyiségét és a kezelési lépések számát. Ezzel az eljárással a nanotekercsek előállításához fontos kaolinit-CTAC komplexet a minták előzetes metanolos kezelése nélkül tudjuk kialakítani. Ezen eljárás kidolgozásához annak az egyszerü ténynek a felismerése kellett, hogy a korábbi kezelések köztes interkalálószere és a végső szilárd reagens oldószere (a metanol) ugyanaz.

Két- és háromlépéses szolvotermális eljárásokkal kaolinit-karbamid, kaolinit-DMSO, kaolinit-NMF prekurzorokból hatékonyan állítottunk elő kaolinit nanotekercseket. ${ }^{28,29,31}$ A termékben 53-66\% arányban elöállított metoxilált kaolinit nanotekercsek bázislaptávolsága változó 0,76-0,90 nm volt. A nanotekercsek külső átmérője 22-75 nm, hossza 218-2287 nm, hossz/átmérö aránya 5-74 között volt. Kísérleteinkben szorosan együttmüködtünk atomi léptékủ szerkezeti vizsgálatot és molekuláris szimulációt végző egyetemi kollégákkal.

\section{Hivatkozások}

1. Ravaglioli, A.; Krajewski, A. Bioceramics and the human body, Springer: Dordrecht, 1992.

https://doi.org/10.1007/978-94-011-2896-4

2. Hench, L.L. An Introduction to Bioceramics, Imperial College Press: London, 2013. https://doi.org/10.1142/p884

3. Kokubo, T. Bioceramics and their clinical applications, CRC Press: Cambridge, 2008. https://doi.org/10.1533/9781845694227

4. Bakó, Z.; Kotsis, I. Ceram. Int. 1992, 18, 373-378. https://doi.org/10.1016/0272-8842(92)90068-O

5. Kotsis, L.-né; Eniszné, B.M.; Korim, T. Magyar Szabadalom CO 4B 35/447-1996, 1996.

6. Dobrádi, A.; Enisz-Bódogh, M.; Kovács, K.; Balczár, I. Ceram. Int. 2015, 41, 4874-4881.

https://doi.org/10.1016/j.ceramint.2014.12.046

7. Dobrádi, A.; Enisz-Bódogh, M.; Kovács, K.; Korim, T. Ceram. Int. 2016, 42, 3706-3714.

https://doi.org/10.1016/j.ceramint.2015.10.159

8. Kokubo, T.; Ito, S.; Huang, Z.T.; Hayashi, T.; Sakka, S.; Kitsugi, T.; Yamamuro, T. Biomed. Mater. Res. 1990, 24, 331-343. https://doi.org/10.1002/jbm.820240306

9. Dobrádi, A.; Enisz-Bódogh, M.; Kovács, K. Process. Appl. Ceram. 2017, 1, 113-119. https://doi.org/10.2298/PAC1702113D

10. Iannotti, V.; Adamiano, A.; Ausanio, G.; Lanotte, L., Aquilanti, G.; Coey, J.M.D.; Lantieri, M.; Spina, G.; Fittipaldi, M.; Margaris, G.; Trohidou, K.; Sprio, S.; Montesi, M.; Panseri, S.; Sandri, M.; Iafisco, M.; Tampieri, A. Inorg. Chem. 2017, 56, 4446-4458. https://doi.org/10.1021/acs.inorgchem.6b03143

11. Zilm, M.E.; Chen, L.; Sharma, V.; McDannald, A.; Jain,M.; Ramprasat, R.; Wei, M. Phys. Chem. Chem. Phys. 2016, 18, 16457-16465. https://doi.org/10.1039/C6CP00474A

12. Ansar, E. B.; Ajeesh, M.; Yokogawa, Y.; Wunderlich, W.; Varma, H. J. Amer. Ceram. Soc. 2012, 95, 2695-2699. https://doi.org/10.1111/j.1551-2916.2011.05033.x

13. Barabás, R.; Rigó, M.; Eniszné-Bódogh, M. Studia UBB Chemia, 2018, 53, 137-154. https://doi.org/10.24193/subbchem.2018.3.11

14. Jakab, M.; Enisz-Bódogh, M.; Makó, É.; Kovács, K.; Orbán, Sz.; Horváth, B. Process. Appl. Ceram. 2020, 14, 321-328. https://doi.org/10.2298/PAC2004321J

15. Duxson, P.; Provis, J.L.; Lukey, G.C.; van Deventer, J.S.J. Cem. Concr. Res. 2007, 37, 1590-1597. https://doi.org/10.1016/j.cemconres.2007.08.018

16. Roy, D.M. Cem. Concr. Res. 1999, 29, 249-254. https://doi.org/10.1016/S0008-8846(98)00093-3

17. Palomo, A.; Grutzeck, M.W.; Blanco, M.T. Cem. Concr. Res. 1999, 29, 1323-1329. https://doi.org/10.1016/S0008-8846(98)00243-9

18. Worrell, E.; Price, L.; Martin, N.; Hendriks, C.; Meida, L.O. Annu. Rev. Energy Env. 2001, 26, 303-329. https://doi.org/10.1146/annurev.energy.26.1.303

19. Yang, K.H.; Song, J.K.; Song, K.I. J. Cleaner Prod. 2013, 39, 265-272. https://doi.org/10.1016/j.jclepro.2012.08.001

20. Balczár, I.; Kovács, A.; Korim, T.; Makó, É. Ceram. Int. 2016, 42, 15367-15375. https://doi.org/10.1016/j.ceramint.2016.06.182

21. Balczár, I., Korim, T., Hullár, H., Boros, A., Makó É. Constr. Build. Mater. 2017, 137, 216-223. https://doi.org/10.1016/j.conbuildmat.2017.01.121 
22. Yuan, P.; Thill, A.; Bergaya, F. Nanosized Tubular Clay Minerals: Halloysite and Imogolite, Elsevier: Amsterdam, 2016.

23. Bergaya, F.; Lagaly, G. Handbook of Clay Science, Elsevier: Amsterdam, 2013. https://doi.org/10.1016/B978-0-08-098258-8.00028-6

24. Makó, É.; Kovács, A.; Ható, Z.; Zsirka, B.; Kristóf, T. J. Colloid Interface Sci. 2014, 431, 125-131. https://doi.org/10.1016/j.jcis.2014.06.006

25. Makó, É.; Kovács, A.; Ható, Z.; Kristóf, T. Appl. Surface Sci. 2015, 357, 626-634. https://doi.org/10.1016/j.apsusc.2015.09.081

26. Makó, É.; Kovács, A.; Katona, R.; Kristóf, T. Colloid. Surface. A 2016, 508, 265-273. https://doi.org/10.1016/j.colsurfa.2016.08.035

27. Kovács, A.; Makó, É. Colloid. Surface. A 2016, 508, 70-78. https://doi.org/10.1016/j.colsurfa.2016.08.025
28. Makó, É.; Kovács, A.; Antal, V.; Kristóf, T. Appl. Clay Sci. 2017, 146, 131-139. https://doi.org/10.1016/j.clay.2017.05.042

29. Kovács, A. Ph.D. Disszertáció, Pannon Egyetem, 2018.

30. Makó, É.; Kovács, A.; Kristóf, T. Appl. Clay Sci. 2019, 182 , 105287. https://doi.org/10.1016/j.clay.2019.105287

31. Makó, É.; Dódony, I.; Pekker, P.; Pósfai, M.; Kovács, A.; Ható, Z.; Kristóf, T. Appl. Clay Sci. 2020, 198, 105800. https://doi.org/10.1016/j.clay.2020.105800

32. Xu, H.; Jin, X.; Chen, P.; Shao, G.; Wang, H.; Chen, D.; Lu, H.; Zhang, R. Ceram. Int. 2015, 41, 6463-6469. https://doi.org/10.1016/j.ceramint.2015.01.085

33. Yuan, P.; Tan, D.; Annabi-Bergaya, F.; Yan, W.; Liu, D.; Liu, Z. Appl. Clay Sci. 2013, 83-84, 68-76. https://doi.org/10.1016/j.clay.2013.08.027

\section{Development of nonmetallic inorganic functional materials and nanostructures}

In this paper, three major research fields of the Department of Materials Engineering (from the University of Pannonia) are presented, which are related to bioactive ceramics, alkali-activated cements, and kaolinite nanostructures.

In the field of bioactive ceramics, calcium phosphate based biomaterials have an important role in bone replacement application due to their ability to form direct contact with bone tissue. The mechanical properties of bioactive materials limit their range of applications. In order to improve the mechanical strength apatite, whitlockite and wollastonite containing glass-ceramics were prepared. In our studies different crystalline phase forming additives were used in a bioactive glass matrix. Hydroxyapatite-iron oxide (HAIO) nanocomposites are getting an increasing role in various medical and therapeutic applications. In these studies different HAIO nanocomposites were prepared by different wet chemical methods, and their physical, chemical and biological properties were determined.

During the development of alkali-activated cements (AACs), the primary goal is to investigate the usability of alternative raw materials that have little or no cementitious properties. In order to use crystalline and hydraulically unreactive air-cooled blast furnace slag for the production of new types of binders, a new activation method, called mechanochemical activation, was developed. By optimizing technological parameters, the concrete debris from construction and demolition waste is also suitable for the production of AACs. Composite material systems can be produced from natural raw materials (e.g. perlite) or entirely from waste materials, which have thermal insulating properties and are excellent for vibration damping. By developing a special foaming technique, it is possible to create structural materials, which are suitable for acting as catalyst supports or even as catalysts due to their adequate photochemical activity.
In the field of kaolinite nanostructures, the formation of nanoscrolls was investigated to develop such a multi-step intercalation procedure, which requires less time, fewer steps and less amount of reagents. First, the direct intercalation of kaolinite with formamide (F), ammonium acetate (AAc), urea, N-methylformamide (NMF) and dimethyl sulfoxide (DMSO) was studied. Next, the methanol (Me) intercalation of prepared precursors was tested. Finally, the intercalation of cetyltrimethylammonium chloride (CTAC) and the formation of kaolinite nanoscrolls from kaolinite-CTAC complexes were examined. In comparison with the generally applied solution intercalation method, the homogenization intercalation of kaolinite with F, AAc, urea, NMF and DMSO required an order of magnitude lower amount of reagents to achieve high degree of intercalation. The homogenization method (contrary to the mechanochemical one) did not cause any deformation of the kaolinite structure. The degree of intercalation of AAc, NMF, urea and DMSO strongly depended on the aging temperature. While the highest degree of intercalation of AAc was achieved by cooling at $-24^{\circ} \mathrm{C}$, that of DMSO, NMF and urea was achieved by heating at slightly above room temperature. We verified that beside the usually used kaolinite-DMSO complex the eco-friendly kaolinite-urea complex can also be successfully applied for production of the technologically important 1.12-nm kaolinite-Me complex. After drying these complexes, the basal spacing decreased to 0.84 $\mathrm{nm}$ or $0.83 \mathrm{~nm}$. We can give the chemical formula of the dried kaolinite-Me complex as $\mathrm{Al}_{2} \mathrm{Si}_{2} \mathrm{O}_{5}(\mathrm{OH})_{37}\left(\mathrm{OCH}_{3}\right)_{03}$. We established that this methanol-grafted kaolinite can easily be intercalated by liquid Me. After the intercalation of CTAC, the kaolinite-CTAC complex was identified at a basal spacing of $3.82 \mathrm{~nm}$ with the chemical formula of $\mathrm{Al}_{2} \mathrm{Si}_{2} \mathrm{O}_{5}(\mathrm{OH})_{37}\left(\mathrm{OCH}_{3}\right)_{03}(\mathrm{CTAC})_{16}(\mathrm{Me})_{16}$. In the case of the production of kaolinite nanoscrolls, the twostep solvothermal treatment of kaolinite-urea precursor yielded the highest efficiency, where the cointercalation of CTAC and Me was achieved. The methanol-grafted nanoscrolls have a variable but larger basal spacing (from 0.76 to $0.90 \mathrm{~nm}$ ). Their external diameters range from 22 to $75 \mathrm{~nm}$, lengths from 218 to $2287 \mathrm{~nm}$, aspect ratios from 5 to 74 . 